\title{
14q32.3-qter trisomic segment: a case report and literature review
}

\author{
Nicoletta Villa ${ }^{{ }^{*}}$, Agnese Scatigno ${ }^{2}$, Serena Redaelli ${ }^{3}$, Donatella Conconi ${ }^{3}$, Paola Cianci ${ }^{2}$, Clotilde Farina ${ }^{4}$, \\ Chiara Fossati $^{2}$, Leda Dalprà ${ }^{1,3}$, Silvia Maitz ${ }^{2}$ and Angelo Selicorni ${ }^{2}$
}

\begin{abstract}
Background: Segmental duplication of the long arm of chromosome 14 (14q) has commonly been reported to affect the proximal segment of $14 \mathrm{q}$, while distal duplication is a rare condition and often associated with segmental monosomy of other chromosomes.

Case presentation: We report the clinical and genetic characterization of a 4-year-old male patient with 14q32.3qter trisomy resulting from an adjacent segregation of a paternal reciprocal translocation (14;21)(q32.1;p12). The child shows minor facial anomalies, severe developmental delay, growth retardation, and a history of congenital hypothyroidism and neonatal transitory hyperglycemic crises.

Conclusions: To the best of our knowledge, only 15 other cases of segmental 14q trisomy were documented. We compared molecularly defined cases to identify a minimal common duplicated region and to find genes with a hypothetical role in the phenotype. The presented case supports the previous suggestion of a pure "distal $14 \mathrm{q}$ partial duplication" and underlines the clinical variability.
\end{abstract}

Keywords: Translocation (14; 21), 14q32.3-qter duplication, Array-CGH

\section{Background}

Genomic rearrangements originate in the architecture of genome causing many Mendelian disorders and influencing various complex traits [1]. Sequences with a high level of homology, dispersed within and inter chromosomes, are the basis of an incorrect pairing followed by recombination; this mechanism is known as Non Allelic Homologous Recombination (NAHR). For instance, the exchange of chromosomal regions between two non homologous chromosomes, which contain paralogous repeats (also known as segmental duplications), produce a translocation.

Carriers of balanced reciprocal translocations have a high reproductive risk of conceiving chromosomally abnormal embryos, leading to recurrent pregnancy loss or birth of affected offspring [2].

The presented case (proband) is the results of a meiotic missegregation of a translocation between the 14q terminal region and a homologous sequence tract of the $21 \mathrm{p}$ arm

* Correspondence: n.villa@asst-monza.it

${ }^{1}$ Medical Genetics Laboratory, San Gerardo Hospital, Monza, Italy

Full list of author information is available at the end of the article (father carrier). Therefore, the child is a carrier of a triple region $14 \mathrm{q}$ and shows a pathological phenotype.

This abnormality has commonly been reported to affect the proximal segment of $14 \mathrm{q}$, while distal duplication is a rare condition often associated with monosomic segment of other chromosomes. Only 11 cases with a pure $14 \mathrm{q}$ duplication are reported in the literature (Tables 1 and 2) [3-13] and only four other cases are present in Decipher database with a brief phenotypic description (Table 3; https://decipher.sanger.ac.uk/). Nine out of 16 cases (including the present one) have a molecular characterization (Fig. 3) [10-13 and 2587, 250364, 286004, 286145 from Decipher Database]. The region involved ranges from $14 \mathrm{q} 31.2$ to the terminal region, q32.33.

The phenotype of the present case is compared with those described in literature and this allows us to identify a minimal overlapping region in 8 out of 9 cases characterized from a molecular point of view, including disease-associated genes.

Despite the rarity of distal 14q duplication, a distinctive phenotype is emerging and is characterized by low birth weight, growth retardation, psychomotor retardation, hypotonia and facial dysmorphisms. 
Table 1 Summary of clinical features from the literature review of 8 cases of distal 14q duplication (in situ) and present case

\begin{tabular}{|c|c|c|c|c|c|c|c|c|c|}
\hline & Present case & $\begin{array}{l}\text { Trunca } \\
\text { et al. [3] }\end{array}$ & $\begin{array}{l}\text { Orye } \\
\text { et al. [4] }\end{array}$ & $\begin{array}{l}\text { Carr } \\
\text { et al. [5] }\end{array}$ & $\begin{array}{l}\text { Masada } \\
\text { et al. [7] }\end{array}$ & $\begin{array}{l}\text { Chen } \\
\text { et al. [10] }\end{array}$ & $\begin{array}{l}\text { Thiel } \\
\text { et al. [11] }\end{array}$ & $\begin{array}{l}\text { Chen } \\
\text { et al. [12] }\end{array}$ & $\begin{array}{l}\text { Sgardioli } \\
\text { et al. [13] }\end{array}$ \\
\hline duplicated region & $\begin{array}{l}\text { q32.13q32.3 } \\
\text { paternal } \\
\text { translocation }\end{array}$ & $\begin{array}{l}\text { q31qter } \\
\text { maternal } \\
\text { inversion }\end{array}$ & $q 24 q 32$ & q31qter & $\begin{array}{l}\text { 32.11qter } \\
\text { de novo } \\
\text { duplication }\end{array}$ & $\begin{array}{l}\text { q31.3q32.3 } \\
\text { de novo } \\
\text { duplication }\end{array}$ & $\begin{array}{l}\text { q32.2qter } \\
\text { de novo } \\
\text { duplication }\end{array}$ & $\begin{array}{l}\text { q31.3q32.12 } \\
\text { de novo } \\
\text { duplication }\end{array}$ & $\begin{array}{l}\text { q31.3qter } \\
\text { maternal } \\
\text { inversion }\end{array}$ \\
\hline age at diagnosis & 1 y $5 \mathrm{~m}$ & $9 \mathrm{~m}$ & $6 \mathrm{~m}$ & $29 y$ & birth & 45 days & $8 y$ & $\mathrm{PD}, 6 \mathrm{~m}$ & 20 days \\
\hline patient sex & male & female & male & female & female & female & female & male & female \\
\hline small at birth & + & + & - & & - & - & + & - & + \\
\hline MR or DD & + & + & + & + & & + & + & - & + \\
\hline microcephaly & + & & & + & & + & - & - & + \\
\hline hypothyroidism & + & & - & - & & & + & & + \\
\hline $\begin{array}{l}\text { prominent/high } \\
\text { forehead }\end{array}$ & + & + & + & & + & + & + & - & + \\
\hline hypertelorism & + & & + & + & - & + & + & - & + \\
\hline $\begin{array}{l}\text { down slanting } \\
\text { palpebral fissures }\end{array}$ & - & - & + & - & - & + & - & - & + \\
\hline $\begin{array}{l}\text { broad and flat nasal } \\
\text { bridge }\end{array}$ & + & & & & + & - & + & - & + \\
\hline bulbous nasal tip & + & & + & & + & & + & & \\
\hline anteverted nares & + & & + & & + & & - & & + \\
\hline $\begin{array}{l}\text { dysplastic/hypoplastic } \\
\text { ear helices }\end{array}$ & - & + & - & + & + & + & + & - & \\
\hline short philtrum & - & & - & & - & & + & - & + \\
\hline $\begin{array}{l}\text { thin upper lip with } \\
\text { exaggerated Cupid's } \\
\text { bow }\end{array}$ & + & + & + & + & + & + & + & - & + \\
\hline broad mouth & + & & & - & + & + & + & - & + \\
\hline micrognathia & - & + & + & & + & - & + & - & \\
\hline $\begin{array}{l}\text { brachydacytly/ } \\
\text { clinodactyly }\end{array}$ & - & & & $\begin{array}{l}\text { digital } \\
\text { anomalies }\end{array}$ & & + & + & & $\begin{array}{l}\text { hypoplastic } \\
\text { fingers }\end{array}$ \\
\hline high palate & - & + & - & - & + & - & & & \\
\hline $\begin{array}{l}\text { partial agenesis/ } \\
\text { hypoplasia of corpus } \\
\text { callosum }\end{array}$ & + & & - & $\begin{array}{l}\text { central } \\
\text { cerebral } \\
\text { atrophy }\end{array}$ & & - & - & - & \\
\hline $\begin{array}{l}\text { congenital heart } \\
\text { defect }\end{array}$ & + & & - & - & $+\mathrm{ASD}$ & $\begin{array}{l}+ \text { patent } \\
\text { ductus } \\
\text { arteriosus }\end{array}$ & - & - & $+\mathrm{ASD}$ \\
\hline neural tube defect & - & - & - & & & - & - & - & \\
\hline diaphragmatic hernia & - & & - & & + & - & & - & + \\
\hline $\begin{array}{l}\text { gastroesophageal } \\
\text { reflux disease }\end{array}$ & + & & & + & & & & - & + \\
\hline hypotonia & + & + & + & & & + & & - & + \\
\hline umbilical hernia & + & & - & & + & - & & - & + \\
\hline
\end{tabular}

+: present; -: absent; $M R$ mental retardation, $D D$ developmental delay, $A S D$ atrial septal defect

\section{Case presentation}

The male patient was born at 34 weeks gestation, by caesarean section in twin pregnancy (assisted reproduction, In Vitro Fertilization). Parents are apparently healthy and not consanguineous; maternal age was
38 and paternal age was 42 years at delivery. One spontaneous abortion was reported by the couple before this pregnancy. Two of the father's sisters died during the first months of life for an unspecified heart malformation and no other information was available. Maternal 
Table 2 Summary of clinical features of published cases of distal 14q trisomic segment derived from translocations and present case

\begin{tabular}{|c|c|c|c|c|}
\hline duplicated region & $\begin{array}{l}\text { Present case } \\
\text { q32.13q32.33 21p pat }\end{array}$ & $\begin{array}{l}\text { Mikelsaar et al. [6] } \\
\text { q24q32 ins }(4 ; 14) \text { pat }\end{array}$ & $\begin{array}{l}\text { Carter et al. [8] case } 4 \\
\text { q32.1qter } 21 p \text { de novo }\end{array}$ & $\begin{array}{l}\text { Sutton et al. [9] } \\
\text { q32.3qter 22p mat }\end{array}$ \\
\hline age at diagnosis & 1 y $5 \mathrm{~m}$. & $9 \mathrm{~m}$ & $1 y$ & $3 y$ \\
\hline patient sex & male & female & male & female \\
\hline small at birth & + & + & & + \\
\hline MR or DD & + & + & + & + \\
\hline microcephaly & + & & & + \\
\hline hypothyroidism & + & - & & \\
\hline prominent/high forehead & + & + & & - \\
\hline hypertelorism & + & & & + \\
\hline down slanting palpebral fissures & - & & & \\
\hline broad and flat nasal bridge & + & & & \\
\hline bulbous nasal tip & + & & & - \\
\hline anteverted nostrils & + & & & \\
\hline dysplastic/hypoplastic ear helices & - & & & + \\
\hline short philtrum & - & & & - \\
\hline thin upper lip with exaggerated Cupid's bow & + & + & & \\
\hline broad mouth & + & & & + \\
\hline micrognathia & - & + & & + \\
\hline brachydacytly/clinodactyly & - & & & \\
\hline high palate & - & + & & \\
\hline partial agenesis/hypoplasia of corpus callosum & + & - & & + \\
\hline congenital heart defect & + & - & & + VSD, ASD aortic conus \\
\hline neural tube defect & - & - & & + myelomeningocele \\
\hline diaphragmatic hernia & - & & & \\
\hline gastroesophageal reflux disease & + & & & \\
\hline hypotonia & + & & + & + \\
\hline umbilical hernia & + & & & \\
\hline
\end{tabular}

+: present; -: absent; MR mental retardation, DD developmental delay, VSD ventricular septal defect, $A S D$ atrial septal defect

family history was unremarkable. The patient's twin sister was healthy.

The pregnancy was uneventful until 22 weeks gestation, when standard ultrasound scan showed severe intrauterine growth restriction (IUGR) of one twin, with a severe pathological doppler gradient, and oligohydramnios. Cerebellar malformation was also present; a prenatal cerebral magnetic resonance imaging (MRI) was performed but no abnormalities were detected. Fetal anatomy looked normal for gestational age.

Patient's birth weight was 780 gr $(<<3$ rd percentile), length $35 \mathrm{~cm}(<<3$ rd percentile) and head circumference $26 \mathrm{~cm}(<<3$ rd percentile). Apgar score was 5 at 1 st minute and 8 at 5 th minute. No facial dysmorphisms were reported but short extremities and restrictive thorax were observed.
In the newborn period and in the first 12 months of life the baby suffered from various medical problems related to prematurity and oligohydramnios sequence: mild Respiratory Distress Syndrome, 1st degree bilateral intraventricular hemorrhage of 1st degree, late anemia, sepsis, osteopenia and meconium ileus (treated with ileostomy placement); he also developed parenteral nutritioninduced cholestasis. His growth was severely delayed and a gastro-esophageal reflux disease was also evident.

The child had hypoplastic kidneys with first stage chronic kidney failure and experienced hyperglycemic crises with metabolic non-ketotic acidosis during episodes of hyperthermia. Echocardiographic evaluation, performed at the age of 1 year, showed dilatation and hypertrophy of right ventricle, small apical interventricular septal defect and patent foramen ovale, right cardiac 
Table 3 Summary of clinical features from 4 cases of distal 14q duplication from decipher database (https://decipher.sanger.ac.uk/) and present case

\begin{tabular}{|c|c|c|c|c|c|}
\hline & Present case & 2587 & $250364^{a}$ & 286004 & 286145 \\
\hline duplicated region & $\begin{array}{l}\text { q32.13q32.33 } \\
\text { 21p pat }\end{array}$ & $\begin{array}{l}\text { q32.2q32.33 } \\
\text { de novo }\end{array}$ & $\begin{array}{l}\text { q31.2q32.33 } \\
\text { de novo }\end{array}$ & $\begin{array}{l}\text { q31.3q32.31 } \\
\text { not reported }\end{array}$ & $\begin{array}{l}\text { q32.12q32.33 } \\
\text { de novo }\end{array}$ \\
\hline age at diagnosis & 1y $5 \mathrm{~m}$. & not reported & $1 y$ & $2 y$ & $2 y$ \\
\hline patient sex & male & not reported & female & male & female \\
\hline small at birth & + & + & & & \\
\hline MR or DD & + & + & & + & + \\
\hline microcephaly & + & & & & \\
\hline hypothyroidism & + & & & & \\
\hline prominent/high forehead & + & + & & + & + \\
\hline hypertelorism & + & + & & & \\
\hline down slanting palpebral fissures & - & & & & \\
\hline broad and flat nasal bridge & + & & & & \\
\hline bulbous nasal tip & + & & & & \\
\hline anteverted nostrils & + & & & & \\
\hline dysplastic/hypoplastic ear helices & - & & & & \\
\hline short philtrum & - & & & & \\
\hline thin upper lip with exaggerated Cupid's bow & + & & & & \\
\hline broad mouth & + & + & & & \\
\hline micrognathia & - & + & & & \\
\hline brachydacytly/clinodactyly & - & + & & & \\
\hline high palate & - & & & & + \\
\hline partial agenesis/hypoplasia of corpus callosum & + & & + & & \\
\hline congenital heart defect & + & & $+\mathrm{ASD}$ & & \\
\hline neural tube defect & - & & & & \\
\hline diaphragmatic hernia & - & & & & \\
\hline gastroesophageal reflux disease & + & & & & \\
\hline hypotonia & + & & & + & + \\
\hline umbilical hernia & + & & & & \\
\hline
\end{tabular}

${ }^{a}$ the database reports: abnormality of the face; +: present; -: absent; $M R$ mental retardation, $D D$ developmental delay, $A S D$ atrial septal defect

failure and secondary pulmonary hypertension. Cerebral MRI reported a thin corpus callosum, polymicrogyria, trigonal cortical heterotopia. Electroencephalography was characterized by paroxysmal record but no epilepsy crises were evident. Metabolic expansive screening and visual evoked potentials were normal. He failed the auditory brainstem response test but subsequent audiological studies were normal. Ophthalmologic evaluations showed moderate excavation of the optic disk. Hormonal studies showed a congenital central hypothyroidism with a hypoplastic thyroid gland; somatotropic hormone levels were slightly low despite adequate growth hormone levels were (IGF-1 levels $<25 \mathrm{ng} / \mathrm{ml}$ with basal GH $8.6 \mathrm{ng} / \mathrm{mL}$ ). Adrenal function and calcium and phosphate metabolism were normal. A negative sweat test excluded cystic fibrosis. Peroxisomal defects were also excluded on fibroblast culture. He had a nasogastric feeding tube until 15 months of age. At 18 months, his height was $60.5 \mathrm{~cm}(<<3 \mathrm{rd}$ percentile), weight $4.300 \mathrm{~kg}$ $(<<3$ rd percentile) and head circumference $43 \mathrm{~cm}$ $(<<3$ rd percentile). His face showed coarse features with frontal bossing, depressed nasal bridge with anteverted nostrils, hypoplasia of the zygomatic bones, accentuated and prominent philtrum, macrostomia, macroglossia, thick and tented upper-lip (Fig. 1). Hepatomegaly, umbilical hernia and asymmetry of lower limbs both in volume and length were also present. Neurological examination showed marked persistent axial hypotonia. 

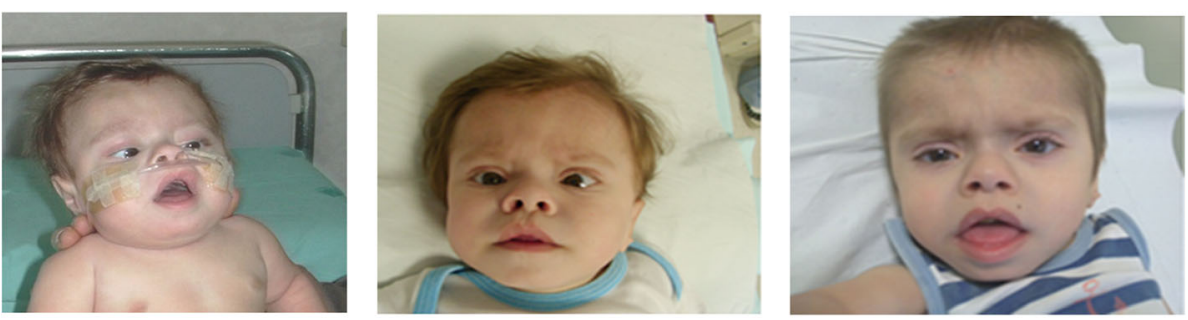

present case: $5 \mathrm{~m} ., 18 \mathrm{~m} ., 2 \mathrm{y}$. and $7 \mathrm{~m}$.
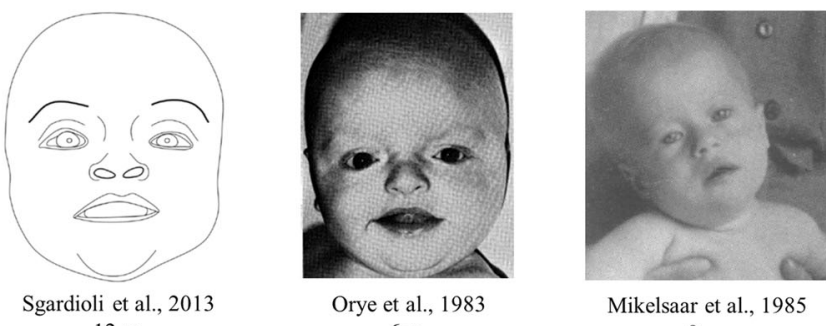

Mikelsaar et al., 1985 $9 \mathrm{~m}$.

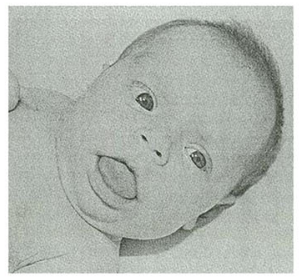

Masada et al., 1989 $6 \mathrm{~m}$. $12 \mathrm{~m}$.
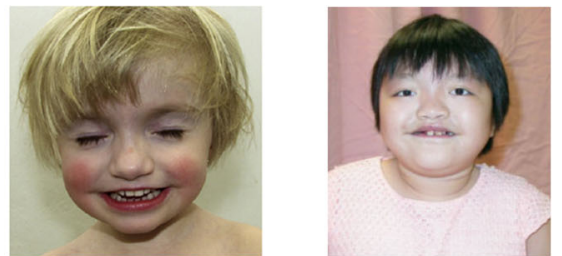

patient $2,3 \mathrm{~m}$.

Chen et al., 2005 $11 \mathrm{y}$. and $8 \mathrm{~m}$.

Fig. 1 Facial features of the patient at different ages compared with literature reported faces

At 2 years and 7 months, his height was $62.5 \mathrm{~cm}(<<3 \mathrm{rd}$ percentile), weight $5.150 \mathrm{~kg}(<<3 \mathrm{rd}$ percentile) and head circumference $44 \mathrm{~cm}$ ( $<<3$ rd percentile). He gained head and trunk control; axial hypotonia was important. Figure 1 reports three images of the child at different ages in comparison with faces of patients with $14 \mathrm{q}$ trisomic segment reported in the literature $[3,5,6,9,10,12]$.

At his last evaluation, the patient was 4 years and 9 months old, his height was $65.5 \mathrm{~cm}$ ( $<<3$ rd percentile), weight $6.680 \mathrm{~kg}$ (<<3rd percentile) and head circumference was $45 \mathrm{~cm}(<<3 \mathrm{rd}$ percentile). The language was absent, but he was able to crawl.

Prenatal diagnosis was performed on amniotic fluid sample because of IUGR and suspected cerebellar malformation identified at 22 weeks gestation in one twin. Only fetal karyotype analysis on the affected twin was done and a normal male result was obtained. At birth, uniparental disomy study for chromosomes 7 and 11 was performed, and the analysis showed biparental origin for both chromosomes (data not shown).

At 18 months of age, karyotype revaluation was required and fluorescence in situ hybridization (FISH) for all subtelomeric regions, performed according to the manufacturer's specifications (Cytocell), showed normal hybridization signals for all chromosomes except for chromosome 14. Proband's metaphases showed three hybridization signals: two at the end of the $\mathrm{q}$ arm of both chromosomes
14 and a third signal on the p arm of a chromosome 21, so the child was a carrier of a triple copy of 14q32.1qter region (Fig. 2a, b). Karyotype and FISH analysis of parents showed a half cryptic translocation between chromosome 14 (14q showing satellites) and 21 (p) in the father (Fig. 2c, d, e): 46,XY,t(14;21)(q32.1;p12).ish t(14;21)(DJ820M16;DJ820M16+).

Array Comparative Genomic Hybridization (Array$\mathrm{CGH}$ ) analysis, performed using $\mathrm{CGH}+\mathrm{SNP} 4 \mathrm{x} 180 \mathrm{~K}$ microarray kit (Agilent Technologies), identified a 11.44 Mb duplication on chromosome $14 \mathrm{q}$ arm from nt $95,849,002(14 q 32.13)$ to $n t 107,287,505$ (14q32.33) in the child (genome version hg19).

The karyotype, defined following International System of Chromosome Nomenclature 2013, was: 46,XY.ish der(21) $\mathrm{t}(14 ; 21)(\mathrm{q} 32.1 ; \mathrm{p} 12)$.ish $\mathrm{t}(14 ; 21)(\mathrm{DJ} 820 \mathrm{M16}+)$.arr 14q32.13q3 2.33(95,849,002-107,287,505)x3 (Fig. 2f).

Uniparental disomy study for chromosomes 14 was performed, and the analysis showed biparental origin for both chromosomes (data not shown).

\section{Discussion}

After prenatal normal karyotype result, no further study was required. The proband showed a pathologic phenotype in postnatal life, so karyotype revaluation was performed. Subtelomeric FISH and array-CGH analysis allowed to identify a trisomic portion of $14 \mathrm{q}$ localized on $21 \mathrm{p}$ arm. 

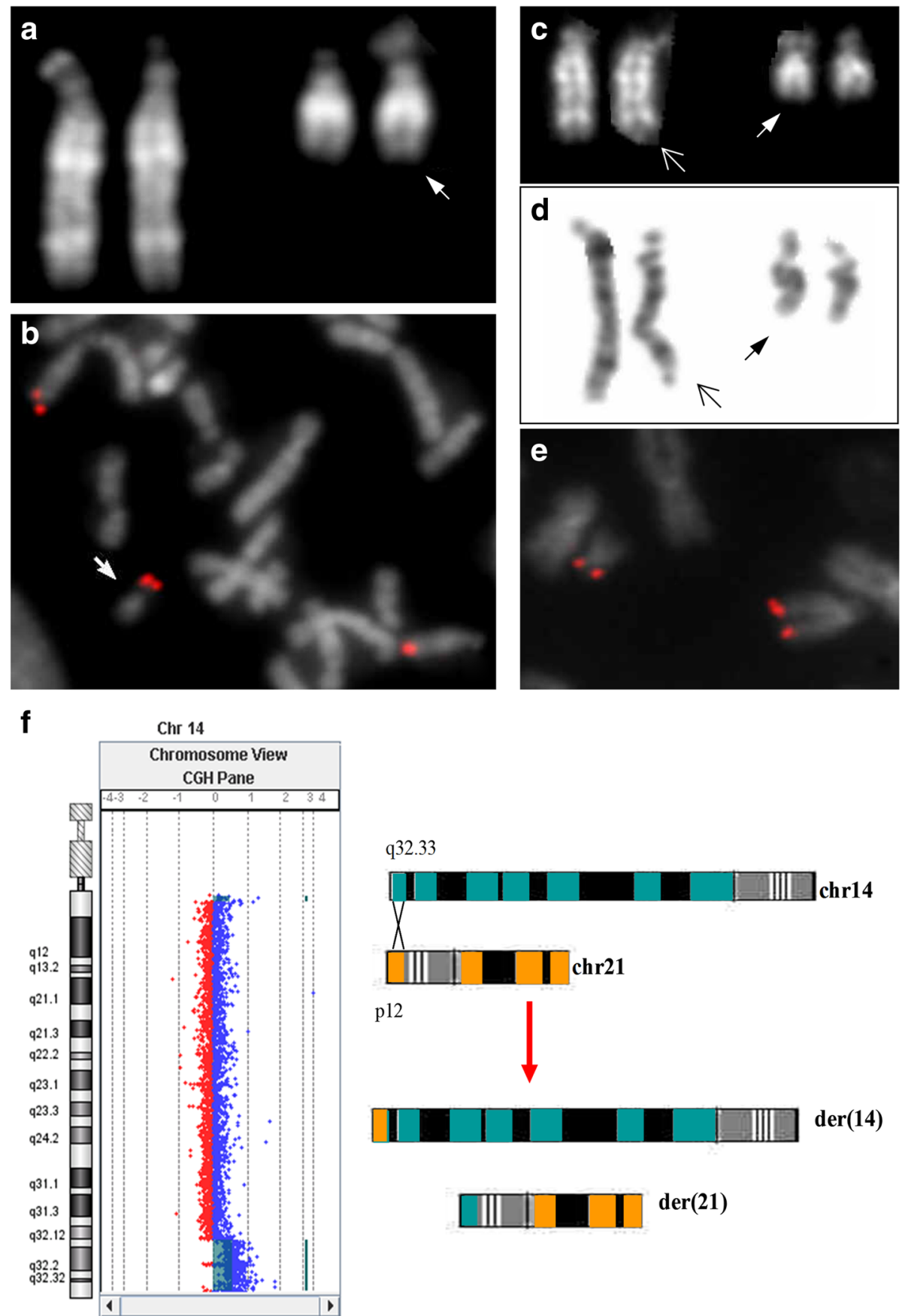

$\mathrm{q} 32.33$

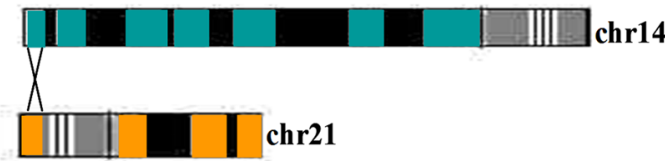

p12
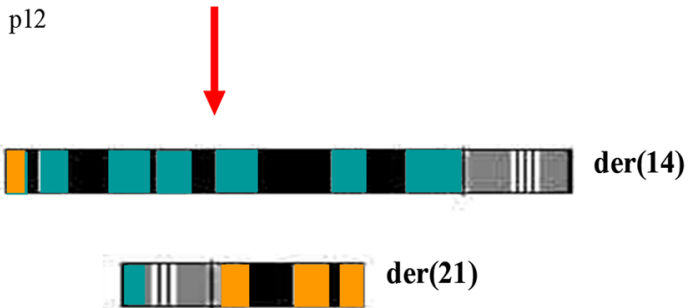

Fig. 2 Cytogenetic, FISH and array-CGH studies. a Proband's QFQ-banded chromosomes 14 and 21; the arrow shows the derivative 21. b FISH with subtelomeric 14q probe of the proband: the der(21) is arrowed. c Father's QFQ-banded partial metaphase with two derivative chromosomes arrowed. d Father's GTG-banded partial metaphase with two derivative chromosomes arrowed. e FISH with subtelomeric 14q probe of the father: hybridization signals are present on the normal 14 and on der(21). $\mathbf{f}$ Chromosome 14 view showing the duplication in array-CGH (left) and a schematic representation of supposed NAHR mechanism for translocation formation (right)

The paternal karyotype contained a balanced translocation which was inherited as unbalanced by the child.

A research of homology between the terminal region of chromosome $14 \mathrm{q}$ and the $\mathrm{p}$ arm of chromosome 21 , through UCSC genome browser (https://genome.ucsc.edu/) and Ensemble (http://www.ensembl.org/index.html), showed a stretch of repetitive sequences of about $1.8 \mathrm{~kb}$ with a $96 \%$ of homology in 14q32.33 (from nt 106,634,089 to nt 
106,635,918) and 21p11.2 (from nt 10860733 to nt 10862578) with inverted orientation. Therefore a non allelic homologous recombination event, mediated by the high level of sequence homology between these two regions, could be the underlying mechanism of balanced translocation formation in the father (Fig. 2f).

To the best of our knowledge, incomplete trisomy of $14 \mathrm{q}$ has been reported in very few clinically documented cases [3-13]: we found a total of 11 comparable cases in the literature and other 4 cases in Decipher database (Tables 1, 2, 3 and 4). Decipher cases are molecularly well defined but lack of a detailed clinical description, follow-up and images, make difficult the comparison with literature. 8 out of 11 case reports, had distal $14 \mathrm{q}$ direct duplications $[3-5,7,10-13]$, the remaining 3 showed translocation derivatives: the first involving a

Table 4 Summary of clinical features from the literature review of 11 cases of distal $14 q$ duplication and present case

\begin{tabular}{|c|c|c|}
\hline & Literature & Present Case \\
\hline \multicolumn{3}{|l|}{ Major Malformation } \\
\hline neural tube defect & 1 & - \\
\hline corpus callosum partial agenesis & 1 & + \\
\hline heart defect & 4 & + \\
\hline diaphragmatic hernia & 2 & - \\
\hline umbilical hernia & 2 & + \\
\hline \multicolumn{3}{|l|}{ Minor Anomalies } \\
\hline prominent/high forehead & 7 & + \\
\hline downslanted palpebral fissure & 3 & - \\
\hline hypertelorism & 6 & + \\
\hline dysplastic/hypoplastic ear helices & 6 & + \\
\hline broad and/or flat nasal bridge & 3 & + \\
\hline bulbous nasal tip & 3 & + \\
\hline high palate & 3 & + \\
\hline short philtrum & 2 & - \\
\hline broad mouth & 5 & + \\
\hline $\begin{array}{l}\text { thin upper lip with exaggerated } \\
\text { Cupid's bow }\end{array}$ & 8 & + \\
\hline micrognathia & 6 & + \\
\hline digital anomalies & 4 & - \\
\hline \multicolumn{3}{|l|}{ Medical Complications } \\
\hline hypotonia & 6 & + \\
\hline hypothyroidism & 2 & + \\
\hline \multicolumn{3}{|l|}{ Growth and Development } \\
\hline microcephaly & 4 & + \\
\hline small at birth & 5 & + \\
\hline developmental delay & 9 & + \\
\hline
\end{tabular}

+: present; -: absent 21p arm [8], similarly to the presented case, the second a 22p arm [9] and the third an insertion into chromosome $4 \mathrm{q}$ [6]. Reportedly, the loss of acrocentric p arm in the translocated cases has no phenotypical consequence.

Our patient shows clinical features common to most types of autosomal chromosome imbalance, such as prenatal growth retardation, physical and psychomotor retardation, but minor facial dysmorphisms (high forehead, mild hypertelorism, broad nasal bridge, broad mouth), supporting the existence of a possible dysmorphic pattern caused by this trisomic $14 \mathrm{q}$ terminal segment (Fig. 1 and Table 4). We observed a higher prevalence of affected females (10 females versus 5 males), but it could be due to the small number of reported patients. The age at diagnosis was early, within the first year for 7 cases and earlier than 8 years for the remaining ones, with the exception of one case diagnosed at 29 years.

No particular differences were evident when unbalanced translocated (Table 2) and in situ duplicated patients (Table 1) were compared, indicating the absence of a positional effects.

The minimum common region among the different cases (Fig. 3), includes a part of DLK1-DIO3 region which contains not only paternally $(D L K 1, R T L 1)$ and maternally (MEG3, MEG8) imprinted genes, but also a stretch of about 50 miRNA involved in growth and development with important regulatory functions. This is the largest cluster of miRNAs in the human genome but, to our knowledge, only miR-134 seems to be involved in mammalian brain maturation, especially in dendrite development [14]. The others appear to play roles in the onset and progression of cancers.

DLK1 gene (OMIM 176290) is a member of Notch signalling pathway involved in cell differentiation [14], interestingly it was reported to exhibit loss of imprinting only in IUGR placentas [15]. RTL1 (OMIM 611896) has an essential role in the maintenance of feto-maternal interface and for development of the placenta. Maternally expressed genes MEG3 and MEG8 (OMIM 605636 and 613648) are long non-coding RNAs with unclear function. Imprinting defect of this region cause both paternal and maternal uniparental disomies, that are characterized by two typical distinct phenotypes. The patient here reported is not affected by uniparental disomy.

Moreover, in 3 cases the gained $14 \mathrm{q}$ region was paternal in origin $[5,6,9]$ and maternal in other 4 cases $[3,9$, $11,13]$ : no significant differences in the clinical features were observed underlining the lack of imprinted gene contribution in the phenotype [9]. However, the epigenetic mechanisms and the interactions among genes are not completely understood and their role in the phenotype is so far unknown.

Analysing the other genes we found that $Y Y 1$ gene participates with SIRT1 (present in normal number of 


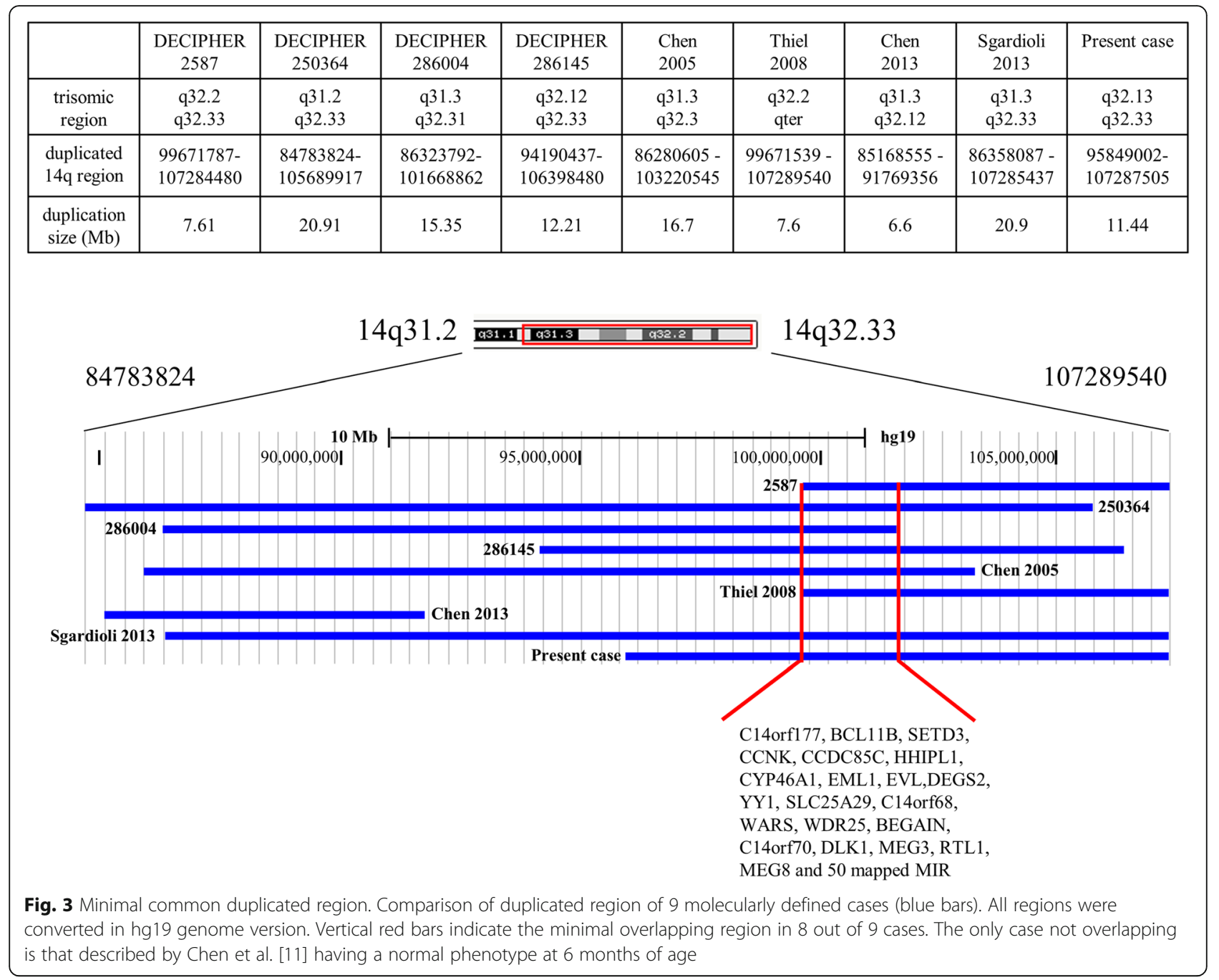

copies) at a repressor complex that normally functions to limit expression of miR134. Change in miR134 expression could result in a downregulation of $C R E B$ and $B D N F$, both involved in the synaptic plasticity [16].

\section{Conclusions}

In conclusion, our observation support the existence of a "distal 14q duplication syndrome" characterized by facial dysmorphisms (high/prominent forehead, hypertelorism, downslanted palpebral fissures, wide flattened nasal bridge, broad mouth, thin upper lip with exaggerated Cupid's bow, micrognathia), hyptonia, growth retardation and developmental delay which may be severe. Further cases will also clarify the incidence of major malformations. Here we found that congenital heart defects are the most frequent major malformations (4 out of 11 patients), while CNS anomaly and kidney hypoplasia, both observed only in our patient, seem to be rare. Furthermore, thyroid involvement will deserve specific attention in patients affected by triple copy of $14 \mathrm{q}$ terminal region, in order to understand its real incidence and pathophysiology.

The present case is an excellent example to argue in favour of a prenatal array-CGH study in cases with severe IUGR and normal standard karyotype and also of karyotype analysis in infertile couples especially in cases with suggestive familiar history.

\section{Abbreviations}

Array-CGH: Array Comparative Genomic Hybridization; FISH: fluorescence in situ hybridization; IUGR: intrauterine growth restriction; MRI: magnetic resonance imaging; NAHR: Non Allelic Homologous Recombination

\section{Acknowledgements}

We thank the Mariani Foundation, Milan, Italy, and the Comitato Maria Letizia Verga, Monza, Italy, for their support for the clinical work at the Pediatric Genetic Unit of MBBM Foundation, S.Gerardo Hospital, Monza, Italy.

Funding

Not applicable.

\section{Availability of data and materials}

The datasets during and/or analysed during the current study available from the corresponding author on reasonable request. 


\section{Authors' contributions}

NV contributed to design the study, performed genetic studies on the patient, collected the literature data and wrote a part of the manuscript. AS, PC, CFa, CFo, SM contributed to design the study, performed the pediatric evaluation of the patient and wrote a part of the manuscript. SR performed array-CGH. DC wrote a part of the article and critically read the manuscript. LD contributed to design the study, wrote a part of the article and critically read the manuscript. AS performed the paediatric evaluation of the patient and contributed to design the study and critically read the manuscript. All authors read and approved the final manuscript.

\section{Competing interests}

The authors declare that they have no competing interests.

\section{Consent for publication}

Written informed consent was obtained from the patient's parents for publication of this case report and any accompanying images.

\section{Author details}

${ }^{1}$ Medical Genetics Laboratory, San Gerardo Hospital, Monza, Italy. ${ }^{2}$ Pediatric Genetic Unit, Pediatric Department of Monza Brianza per il Bambino e la sua Mamma (MBBM) Foundation, San Gerardo Hospital, Monza, Italy. ${ }^{3}$ School of Medicine and Surgery, University of Milano-Bicocca, Milan, Italy. ${ }^{4}$ Neonatal Intensive Care Unit, Pediatric Department at MBBM Foundation, San Gerardo Hospital, Monza, Italy.

Received: 21 March 2016 Accepted: 19 July 2016

Published online: 05 August 2016

\section{References}

1. Lupski JR, Stankiewicz P. Genomic disorders: molecular mechanisms for rearrangements and conveyed phenoptypes. PLoS Genet. 2005;1:e49.

2. Lledó B, Ortiz JA, Morales R, Ten J, de la Fuente PE, et al. The paternal effect of chromosome translocation carriers observed from meiotic segregation in embryos. Hum Reprod. 2010; 25(7):1843-8.3.

3. Trunca C, Opitz JM. Pericentric inversion of chromosome 14 and the risk of partial duplication of $14 q(14 q 31 \rightarrow 14 q 3 t e r)$. Am J Med Genet. 1977;1:21728.

4. Orye $\mathrm{E}$, Van Bever $\mathrm{H}$, Desimpel $\mathrm{H}$. Distal trisomy $14 \mathrm{q}$ due to tandem duplication (q24 $\rightarrow$ q32). Ann Genet. 1983;26:238-9.

5. Carr DM, Jones-Quartey K, Vartanian MV, Moore-Kaplan H. Duplication 14(q31-qter). J Med Genet. 1987;24:372-4.

6. Mikelsaar RV, Ilus TA, Lurie IW. Distal trisomy 14q. J Med Genet. 1987;24:380-1.

7. Masada TC, Olney AH, Fordyce R, Sanger WG. Partial deletion of $14 \mathrm{q}$ and partial duplication of $14 \mathrm{q}$ in sibs: testicular mosaicism for $\mathrm{t}(14 \mathrm{q} ; 14 \mathrm{q})$ as a common mechanism. Am J Med Genet. 1989:4:528-34.

8. Carter NP, Ferguson-Smith MA, Perryman MT, Telenius H, Pelmear AH, et al. Reverse chromosome painting: a method for the rapid analysis of aberrant chromosomes in clinical cytogenetics. J Med Genet. 1992;29:299-307.

9. Sutton VR, Coveler KJ, Lalani SR, Kashork CD, Shaffer LG. Subtelomeric FISH uncovers trisomy 14q32: lessons for imprinted regions, cryptic rearrangements and variant acrocentric short arms. Am J Med Genet. 2002;112:23-7.

10. Chen CP, Chern SR, Lin SP, Lin CC, Li YC, et al. A paternally derived inverted duplication of distal $14 q$ with a terminal $14 q$ deletion. Am J Med Genet. 2005;139:146-50

11. Thiel CT, Dörr HG, Trautmann U, Hoyer J, Hofmann K, et al. A de novo 7. $6 \mathrm{Mb}$ tandem duplication of 14q32.2-qter associated with primordial short stature with neurosecretory growth hormone dysfunction, distinct facial anomalies and mild developmental delay. Eur J Med Genet. 2008;51:362-7.

12. Chen CP, Hwang KS, Su HY, Lin SP, Su YN, et al. Prenatal diagnosis and molecular cytogenetic characterization of a de novo interstitial duplication of $14 q(14 q 31.3 \rightarrow q 32.12)$ associated with abnormal maternal serum biochemistry. Taiwan J Obstet Gynecol. 2013;52:125-8.

13. Sgardioli IC, Simioni M, Viguetti-Campos NL, Prota JR, Gil-da-Silva-Lopes VL. A new case of partial 14q31.3-qter trisomy due to maternal pericentric inversion. Gene. 2013;523:192-4.

14. Benatatos L, Hatzimichael E, Londin E, Vartholomatos G, Loher P, et al. The microRNAs within the DLK1-DIO3 genomic region: involvement in disease pathogenesis. Cell Mol Life Sci. 2012;70:795-814.
15. Diplas Al, Lambertini L, Lee MJ, Sperling R, Lee $Y L$, et al. Differential expression of imprinted genes in normal and IUGR human placentas. Epigenetics. 2009;4(4):235-40.

16. Gao J, Wang WY, Mao YW, Graff J, Guan JS, et al. A novel pathway regulates memory and plasticity via SIRT1 and miR-134. Nature. 2010;466:1105-9.

\section{Submit your next manuscript to BioMed Central and we will help you at every step:}

- We accept pre-submission inquiries

- Our selector tool helps you to find the most relevant journal

- We provide round the clock customer support

- Convenient online submission

- Thorough peer review

- Inclusion in PubMed and all major indexing services

- Maximum visibility for your research

Submit your manuscript at www.biomedcentral.com/submit
) Biomed Central 